\title{
Study on Financial Accounting Norms and Implementation in High-tech Enterprise
}

\section{Fan Zhang}

Yunnan University of Business Management, Kunming, Yunnan, 650106

Keywords: High-tech enterprise; financial accounting; standardization and implementation

\begin{abstract}
In recent years, high-tech enterprises have been increasing, the market scale has been continuously improved, and important contributions have been made to the development of the market economy. The state has introduced a series of policy measures to support the development of high-tech enterprises, and enterprises should start with financial accounting if they want to fully enjoy preferential policies. Financial accounting is an important part of financial management of high-tech enterprises. This paper first defines the relevant concepts and points out the key points and principles of financial accounting for high-tech enterprises. Secondly, this paper points out the problems in the financial accounting of high-tech enterprises. Finally, the norms and implementation strategies for financial accounting of high-tech enterprises are obtained, including: increasing the emphasis on financial accounting, formulating scientific R\&D expense accounting plans, establishing a sound financial management system, and establishing a sound financial budget system.
\end{abstract}

\section{Introduction}

With the continuous advancement of science and technology, people's dependence on science and technology has gradually increased. High-tech enterprises emerged as the times require, not only realized the transformation of scientific and technological achievements into products, but also contributed new growth points to the market economy and became an indispensable part of the market economy. The state has introduced a series of policies to encourage the development of high-tech enterprises, especially tax incentives, so the financial accounting of high-tech enterprises has become an important part of its development. Through the financial accounting process, high-tech enterprises can not only understand their own business conditions, but also carry out effective tax planning, laying a solid foundation for the long-term development of enterprises. Therefore, it is of great significance to the research on the financial accounting norms and implementation of high-tech enterprises.

\section{The key points and principles of financial accounting of high-tech enterprises}

\subsection{Concept definition}

High-tech enterprises refer to enterprises that have registered in China for more than one year, through continuous research on high-tech fields, to achieve the transformation of scientific and technological achievements, and gradually form independent intellectual property rights [ ]. If it is recognized as a high-tech enterprise, the corporate income tax will fall to $15 \%$ and the tax preferential policy can be fully enjoyed. The financial accounting of high-tech enterprises mainly records and accounts for the operation of enterprises through monetary measurement, thus reflecting the true financial status of the enterprise [ ].

\subsection{Key points of financial accounting for high-tech enterprises}

The main function of high-tech enterprises is to realize the transformation of scientific and technological achievements. Therefore, a large amount of investment is needed for research and development. The state has clearly defined the research and development expenses of high-tech 
enterprises (see Table 1), so the accounting of research and development expenses becomes the financial accounting of high-tech enterprises.

Table 1 Provisions for the proportion of R\&D expenses of high-tech enterprises

\begin{tabular}{cc}
\hline $\begin{array}{c}\text { Sales revenue of high-tech enterprises in the } \\
\text { past year (10,000 yuan) }\end{array}$ & R\&D expenditure ratio \\
\hline$<5000$ & not lower than $6 \%$ \\
$5000 \sim 20000$ & not lower than $4 \%$ \\
$>20000$ & not lower than $3 \%$ \\
\hline
\end{tabular}

The research and development expenses of high-tech enterprises mainly include eight aspects: personnel labor, direct investment, depreciation and long-term expectation, design, equipment commissioning and experimental expenditure, amortization of intangible assets, commissioned external research and development and other expenses [ ]. In the process of accounting for research and development expenses, high-tech enterprises should reasonably set up accounting subjects and conduct scientific financial management according to strict financial accounting systems.

\subsection{Principles of financial accounting for high-tech enterprises}

Principle of Prudence: In the process of financial accounting, high-tech enterprises must have a rigorous attitude, carefully record and account for each income and expenditure, and ensure the accuracy of financial accounting. Financial personnel shall not arbitrarily increase or decrease income and expenditure items, and shall not falsely report the profit reported, and the accounting results shall reflect the true operating status of the enterprise [ ].

Normative principle: High-tech enterprises should build a complete financial accounting system and establish a clear financial management system to regulate financial accounting behavior and ensure that financial accounting work is carried out in a standardized and orderly manner.

The principle of comprehensiveness: The financial accounting content of high-tech enterprises should conform to the principle of comprehensiveness. In particular, when conducting research and development expenses accounting, the cost subjects should be fully recorded according to the specific use of research and development expenditures, and the use of financial expenses should be fully reflected.

\section{The problems in the financial accounting of high-tech enterprises}

\subsection{Insufficient attention to financial accounting}

Financial accounting is one of the important contents of corporate financial management. High-tech enterprises only pay attention to financial accounting, and can better carry out tax planning according to tax policies, thus completing financial goals. At present, many enterprises in China do not pay much attention to financial accounting, but only pay attention to the level of profit, but ignore the overall financial planning. High-tech enterprises also face the same problem. Since the history of high-tech enterprises is still not long, enterprises pay more attention to technology research and development and product transformation, and their understanding of financial accounting is not deep, so they lack sufficient attention.

\subsection{The problem of accounting for research and development expenses is outstanding}

First, staff costs are unstable. According to the relevant national policy, the staff involved in the enterprise technology research and development must be the personnel who formally sign the labor contract, or the staff who have worked in the enterprise for 183 days [ ]. However, there are many $\mathrm{R} \& \mathrm{D}$ projects in high-tech enterprises, and there is a certain degree of liquidity in R\&D personnel, and there is a high possibility of changes in personnel expenses. For example, a research and 
development staff may be transferred to another project in one project, and other personnel will take over the rest of the research and development work. The treatment of the two personnel will be different, and the financial expenditure will change.

Second, the cost accounting of the R\&D and development phases is flexible. According to the "New Accounting Standards", the research and development projects are divided into the research and development phase and the development phase, according to which the research and development expenses are divided into expense and capitalization [ ]. In actual work, it is difficult for high-tech enterprises to clearly distinguish between the two stages, and the flexibility in cost accounting is increased. For example, capitalizing the research and development expenses can operate the actual profit and loss of the enterprise. This will have a negative impact on investor decisions.

Third, the failure to fully disclose research and development expenses. China's disclosure of corporate R\&D expenses is not clearly defined, and investors can only obtain relevant information through financial reports. If high-tech enterprises hide the R\&D expenses, they will have problems of incomplete information disclosure and information asymmetry.

\subsection{The financial management system is not sound}

The development history of China's high-tech enterprises is relatively short, and the financial management system is still not perfect. The process of financial accounting is mainly based on the financial management system of the enterprise. If there is no perfect financial management system, the enterprise will face a situation of no rules. In the financial accounting of high-tech enterprises, it is difficult for managers to supervise the whole process of accounting, and there are phenomena of unclear powers and responsibilities, which may easily lead to speculation by employees [ ]. The specific content of the rights and responsibilities should be stated in the financial system. If the system is not perfect, it will cause many problems. In addition, even if some high-tech industries have established a financial management system, there are cases where the update is not timely. As the accounting standards and related policies of financial management are constantly updated, if the enterprise adopts the old financial management system, the system will be ineffective, and it is difficult to constrain the financial accounting process and behavior.

\subsection{The financial budget system is imperfect}

Case: Company A was established in 1999 with a registered capital of 57.37 million yuan. It is a high-tech enterprise in Wuhan, mainly researching and developing bio-pesticide, fertilizer and other products. In recent years, Company A has continuously increased its R\&D investment, but it has not achieved the desired benefits. This is mainly due to problems in its budget management. In the budget preparation process, the traditional budget preparation method is used to deviate from the actual R\&D activities; the budget execution link adjusts the budget at will, disrupts the original plan and forms a vicious circle; in the budget performance evaluation link, there are indicators that are not refined and lacking. Quantitative indicators and other issues.

The above case shows that although the company has prepared a financial budget, there are problems in the way of preparation and implementation, which ultimately leads to deviation from financial objectives and affects financial accounting. For high-tech enterprises, the most important thing is the preparation and implementation of R\&D budget. R\&D activities are often long-term projects. If the company fails to consider the actual needs and blindly prepare the budget, it will lead to deviations in financial objectives. Therefore, high-tech enterprises can only achieve the desired results and benefits if they establish a sound financial budgeting system.

\section{Standardization and implementation of financial accounting for high-tech enterprises}

\subsection{Continuously increase the emphasis on financial accounting}

On the one hand, high-tech enterprises should learn the latest policies and regulations promulgated by the state in a timely manner, explain in detail the new requirements put forward by 
high-tech enterprises, and continuously deepen their understanding of financial accounting. For example, in recent years, China has successively issued a series of policies related to the identification methods and supporting measures related to high-tech enterprises, which put forward higher requirements for corporate financial accounting. Therefore, high-tech enterprises should carry out financial accounting according to the latest policies.

On the other hand, corporate management should increase the emphasis on financial accounting. The management of high-tech enterprises should give full play to the leading role and drive all employees, especially financial related personnel, to raise awareness and ensure the smooth implementation of financial accounting. Only by paying attention to financial accounting, can we better understand relevant policies and regulations, and enjoy preferential policies through effective tax planning, and finally promote the realization of financial goals.

\subsection{Formulating a scientific research and development expense accounting plan}

First, develop a phased personnel cost accounting plan. Due to the flow of personnel during the implementation of the R\&D project, it is more difficult for financial accounting. Therefore, the R\&D project can be divided into several stages and financial accounting is performed at different stages, which not only reduces the financial accounting changes caused by personnel changes, but also improves the efficiency of financial accounting.

Second, the cost accounting for the R\&D and development phases is handled correctly. High-tech enterprises should scientifically divide the research and development stage and the development stage according to the relevant laws and regulations, and correctly carry out the cost and capitalization of the expenses, so as to avoid the situation of capitalizing the two stages of costs.

Finally, strengthen the supervision of disclosure of research and development expenses. From the perspective of external supervision, China should introduce relevant regulations to specify the disclosure of $R \& D$ expenses of enterprises, thereby constraining corporate behavior. Internally, high-tech enterprises should supervise the disclosure of research and development expenses, improve the situation of information asymmetry, and increase investor confidence.

\subsection{Formulating a sound financial management system}

On the one hand, high-tech enterprises should establish a sound financial management system. The financial management system is the basis for the enterprise to carry out financial accounting. Only through the system can the financial accounting behavior be effectively restrained and the behavioral deviation corrected. The financial accounting management system of high-tech enterprises should clearly divide the responsibility rights to avoid unclear responsibilities. In addition, since $R \& D$ expense accounting is a key point in the financial accounting of high-tech enterprises, the management system should focus on its detailed provisions.

On the other hand, high-tech enterprises should update the contents of the financial management system in a timely manner. As China's high-tech enterprises are in a growing situation, new policies and regulations emerge in an endless stream. Therefore, enterprises should timely adjust the financial management system according to the contents of relevant laws and regulations, change the traditional financial accounting methods, and innovate according to their actual conditions. To advance the completion of financial goals.

\subsection{Establishing a sound financial budget system}

First, financial budgeting should be scientific and reasonable. When preparing financial budgets, high-tech enterprises should fully consider the actual situation, especially for projects with long development time, and fully consider the factors of change and prepare a reasonable financial budget. Enterprises must not blindly prepare financial budgets, otherwise it will be difficult to achieve financial goals.

Second, the implementation of the financial budget should be steadily and orderly. During the implementation of the financial budget, high-tech enterprises should effectively control the budget to avoid the situation of arbitrarily changing the budget, so as to avoid the need to adjust the subsequent budget to form a vicious circle, and the budget should be allowed to change within a 
reasonable range.

Finally, the financial budget performance evaluation should be comprehensive and detailed. The financial budget performance evaluation should set comprehensive indicators, and the content of the indicators should be as fine as possible, which can reflect the effect of the financial budget. At the same time, a certain proportion of quantitative indicators should be set to better reflect the effect of the financial budget.

\section{Conclusion}

The development of high-tech enterprises not only requires the promotion of research and development projects and the transformation of scientific and technological achievements, but also requires scientific and effective financial accounting to achieve the expected financial goals. Among them, R\&D expense accounting is the key to financial accounting of high-tech enterprises. Reasonable accounting subjects should be set up for accounting, and a scientific financial accounting plan should be formulated. High-tech enterprises should strengthen their understanding from the ideological point of view and allocate resources more reasonably for financial accounting. At the same time, the establishment of financial management system and budget system can effectively restrain the behavior of financial accounting, which is also crucial for enterprises.

\section{References}

[1] Zhang Ping. Analysis of Key Points in Accounting and Tax Planning of High-tech Enterprises[J]. National Circulation Economy, 2018(24): 92-93.

[2] Du Na. Common problems and improvements in corporate financial accounting [J]. China Township Enterprise Accounting, 2018 (04): 95-96.

[3] Zhu Yinjuan. Research on how to standardize the financial accounting of high-tech enterprises [J]. New Economy, 2016 (06): 115-116.

[4] Qiu Ning. Discussion on Key Points of Financial Work in High-tech Enterprises[J]. China Chief Accountant, 2017(02): 92-94.

[5] Wang Yuming. Analysis of the Application of Prudence Principle in Accounting [J]. Rural Economy and Technology, 2018 (02): 97-98.

[6] Wang Cuiqing. Research and development cost accounting and financial management of high-tech enterprises [J]. Science and Technology Economics Guide, 2018, 26 (18): 198+177.

[7] Qiao Wenchang. Research on the solution strategy of research and development cost accounting for high-tech enterprises[J]. Enterprise Technology Development, 2015, 34(02): 37-38.

[8] Zhang Pingping. The Status Quo of Enterprise Financial Accounting and Countermeasures [J]. SME Management and Technology (first issue), 2018 (03): 84-85.

[9] Yang Yaqin. Research on R\&D Budget Management of High-tech Enterprises--Taking A Enterprise as an Example [D]. Tianjin University of Finance and Economics, 2017. 